\title{
Rockburst hazard assessment based on seismic tomography and analytical modelling - a case study
}

\author{
Dariusz Chlebowski* and Zbigniew Burtan
}

AGH University of Science and Technology, Faculty of Mining and Geoengineering, Krakow, Poland

\begin{abstract}
In accordance with the formal regulations currently in force in Poland, the criteria for rockburst hazard assessment with respect to coal deposits include the records of seismic events and their impacts, de-stressing of the entire seam or its parts and expert opinions of mine operation engineers. Effectiveness of the de-stressing can be verified by geophysical test data whilst the expert opinions are mostly based on mathematical modelling using specialist software or dedicated simulation algorithms. This study collates and synthesises the results of tests carried out in a seam section in a colliery within the Upper Silesia Coal Basin, obtained by the outlined methods. Geophysical survey results are interpreted basing on seismic tomography procedures utilising the geo-tomography techniques for velocity field reconstruction in data processing. For comparison, the stress state modelling data are provided, based on conventional engineering solutions applicable to mechanics of deformable media. The actual assessment of the rockburst threat level is based on observations of distributions of the longitudinal wave velocity in relation to the actual value of the vertical component of stress concentration within the coal seam.
\end{abstract}

Keywords: rockburst hazard, strata de-stressing, analytical modelling, seismic tomography

\section{Introduction}

Mining operation in the conditions of rockburst hazard require effective prevention measures, including long-term and short-term control strategies developed in the mining practice [1]. Broadly-understood rockburst control and forecasting of the rockburst threat levels rely mostly on geophysical methods: seismic and seismoacoustic observations, seismic measurements involving seismic profiling in coal seams and seismic tomography [2-9]. In recent years analytical and numerical methods were also developed and effectively used to determine the range and extent of stress concentration zones, de-stressed regions in the proximity of longwall/shortwall faces and near the development entries [10-11].

De-stressing strategies, understood as technical and organisational measures, are put in place to reduce the stress levels within the deposits and, consequently, to minimise elastic

\footnotetext{
*Corresponding author: chlebo@agh.edu.pl
} 
strains within the rock strata, besides two types of de-stressing effects can be produced: stress relief or strata destruction. The stress relief effect consists in reduction of the stress tensor components within the seam being mined, whilst the destructive effect gives rise to formation of the cracking and fracturing zones within the deposit such that it is no longer able to accumulate elastic energy. According to a widely adopted stress relief strategy, the seams that are not threatened or where the rockburst threat levels are low should be mined first. As a result, in areas adjacent to the mined-out seams most desirable stress changes occur, leading to reduction of respective stress components.

The conditions prevailing in a plot in the coal deposit (shortwall panel AD/510) to be mined in one of the collieries within the former Katowice Mining Holding S.A. are investigated and used in the comparative study of the rockburst threat levels derived by geophysical methods [12] and analytical simulations [13]. Geophysical methods include seismic tomography with the technique of $\mathrm{P}$-wave velocity field reconstruction whilst analytical modelling relies on conventional studies of the state of stress in rock strata affected by the presence of old exploited mine workings, recalling the principles of mechanics of elastic media [14-16].

\section{Geological and mining conditions}

The plot being mined is the shortwall (open-end) panel AD located in the III stratum (roof substrata) in the seam 510, at the depth between 570 to $600 \mathrm{~m}$. The working method involves the cross-end mining with the roof caving whilst the shortwall has its beginning at the crossentry $\mathrm{AD}$ and stretches in the north-east direction. The heading limiting the plot on the western side is the upwards heading no 139, and from the eastern end- the upwards heading no 11/III-115 (Fig. 1).

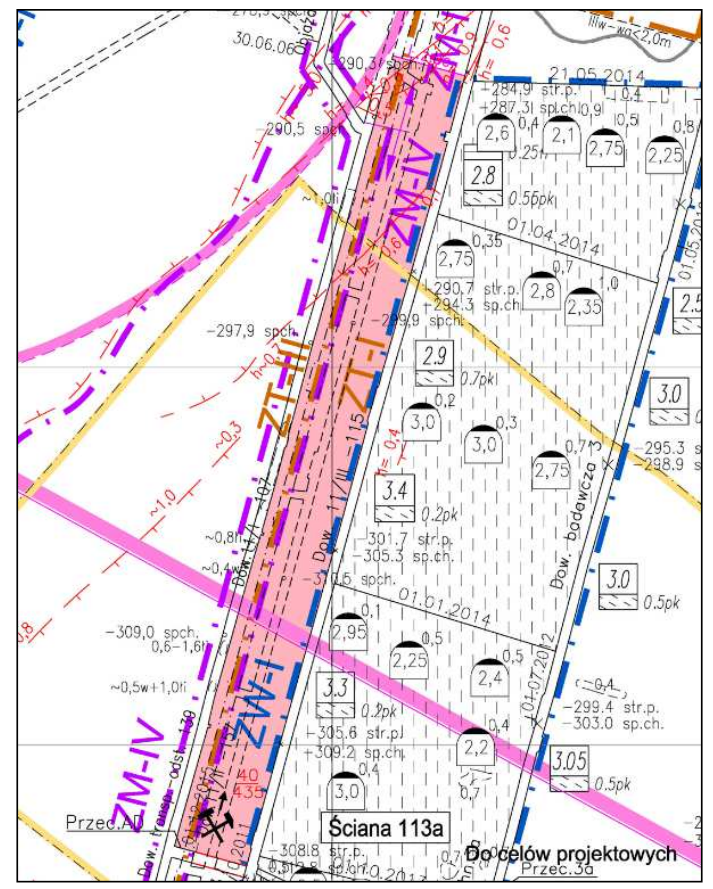

Fig. 1. Map of mine workings in the coalbed 510/III in the region of the shortwall AD. 
Geometric parameters of the shortwall section are: length $40 \mathrm{~m}$, the range $435 \mathrm{~m}$ and height $3.0 \mathrm{~m}$. Initially, the total thickness of the seam 510 in the investigated region ranged from $9.1 \div 10.0 \mathrm{~m}$; the compressive strength of rock strata being $16.3 \div 29.0 \mathrm{MPa}(22.2 \mathrm{MPa}$ on the average). From the eastern side, the panel has the mined-out sections: I (roof strata) and II (intermediate strata) where hydraulic backfilling was employed. The thickness of the panel (roof strata III) to be mined within the seam 510 ranges from 2.7 to $3.7 \mathrm{~m}$, the seam being inclined by about $4^{\circ}$ in the south-west direction [12-13].

Features making up the roof rock and floor strata developed in the form of illite shales and sand-containing illite shales whose uniaxial compressive strength falls in the range $20.5 \div 38.5 \mathrm{MPa}(32.7 \mathrm{MPa}$ on the average). Previous mining operations revealed the presence of a major fault SW-NE, having the displacement of $0.1 \div 0.6 \mathrm{~m}$ in the NW direction. Furthermore, in the northern section of the shortwall panel AD there is a faulting zone SW$\mathrm{NE}$, with the displacement $0.9 \mathrm{~m}$ in the SE direction. In this region other disturbances due to sedimentation can potentially occur: thinner seam sections, faulting, and brittle, fallible rocks in the immediate roof, hence the coal layer $1.0 \mathrm{~m}$ thick has to be left in the shortwall roof. As a result of previous mining activities, the mined-out voids in the layer II of the coalbed 510 are filled with sand left over after backfilling operations, that is why a coal shelf $0.5 \mathrm{~m}$ in thickness was left to prop and stabilise the powered supports, which is a requisite for the effective face advance.

At the distance of about $25 \mathrm{~m}$ from the roof strata in the coalbed 510 there are residues of the backfilling operations and in the final sections of the face range the shortwall mining is continued beyond the edge and in the strata which have not been yet overcut. Beneath the coalbed 510, at the distance of $134 \mathrm{~m}$, there is the coal seam 620 , worked by the longwall mining. Mining operations in this coalbed will be continued beyond the working edges [12$13]$.

\section{State of stress and rockburst hazard assessment in the context of seismic data}

Geophysical methods relying on seismic tomography were applied to evaluate the conditions of the rock strata in the shortwall region, limited by the upwards heading no 139 and 11/III115 and by the cross-cuts $\mathrm{AD}$ and 49 in the coalbed 510 [12]. The main objective was to obtain good-quality seismic images and to derive the times of seismic wave propagation within the coalbed and in its proximity, whilst the actual configuration of geophones and source locations was controlled by availability for testing of the existing mine workings (Fig. 2). The recording time was $500 \mathrm{~ms}$ whilst the length of seismic rays ranged from $34 \div 304 \mathrm{~m}$, enabling the P-waves and S-waves to be effectively registered within the coalbed and in its vicinity. The sampling time in the recording procedure (1000 samples/channel) was $0,5 \mathrm{~ms}$, hence the registered frequency had to be restricted to the threshold value of $1000 \mathrm{~Hz}$. Following the filtering and phase correction, registered seismograms yield the first P-wave arrival times in rock strata surrounding the coalbed being mined. In the further step the Pwave and $\mathrm{S}$-wave velocities along the ray paths were obtained and the adequacy of the computation procedure was verified via the statistical treatment of sets of ray lengths and wave velocities along the ray paths. Correlation analysis and linear regression of the paths and arrival times allow the systematic errors involved in individual path measurements to be eliminated through introduction of the constant correction term, which is of key importance when registering the first arrival times of refracting waves. After incorporation of a correction terms, the observation procedures can be extended beyond the edge of the mined coal bed and to the surrounding rock strata. The analysis of correlation and linear regression in the ray path-velocity system proves most useful in examination of seismic records in the context of refracted wave propagation in the gradient medium, either continuous or discrete, and allows 
for elimination of error due to the first refracted wave arrival being mistaken for the refracting wave [12].

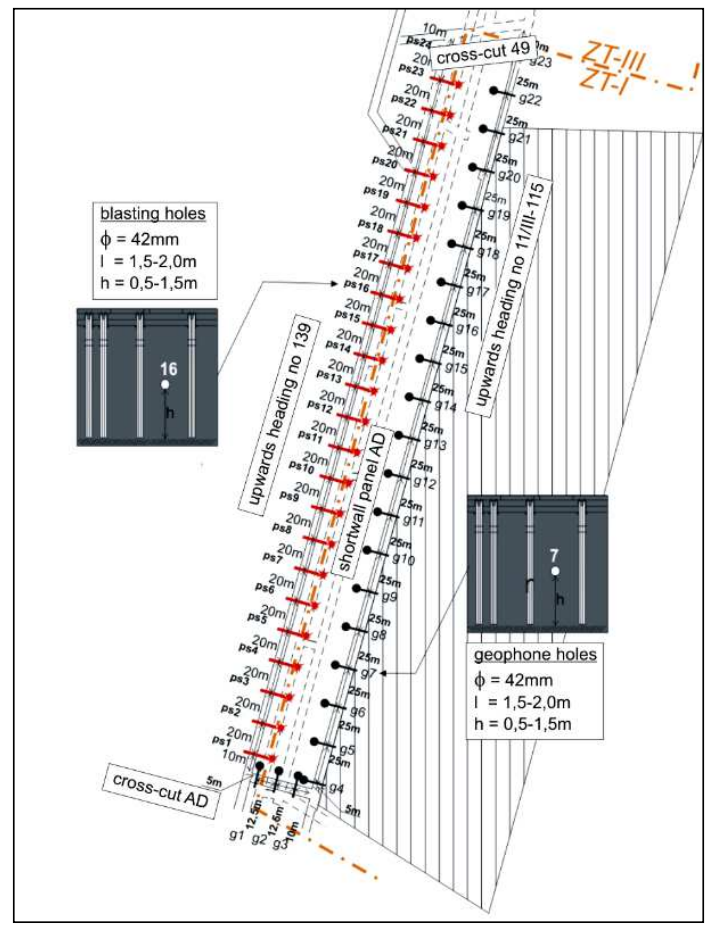

Fig. 2. Layout for seismic tomography survey [12].

In the next step of the procedure the velocity fields of respective waves were reconstructed by the seismic tomography utilizing the SIRT (Simultaneous Iterative Reconstruction Technique). The iterative procedure was repeated until the error involved in reconstruction was effectively reduced to the noise level or levelled off. Accordingly, the measure of the reconstruction error was the standard deviation of the set of differences between the measured and computed times, derived basing on the reconstructed field of wave velocities along the ray paths.

To provide a reliable comparison with simulation data, geophysical measurement data are limited to selected parameters of the velocity field of seismic waves registered within the coalbed whilst the respective wave velocity fields in surrounding rock strata are neglected. The results are collated as contour maps of P-wave velocity (Fig. 3) and the plots of seismic anomaly parameters (Fig. 4). Thus obtained distribution patterns indicate that P-wave velocity $\left(\mathrm{V}_{\mathrm{PW}}\right)$ along the ray path when propagating within the coalbed is variable in the range $1400 \div 1900 \mathrm{~m} / \mathrm{s}$. Reconstructed velocity fields fall in the similar range and the mean radial velocity and mean velocity of the reconstructed field becomes $1725 \mathrm{~m} / \mathrm{s}$. The anomaly parameter $\left(A_{S}\right)$ is calculated in relation to the P-wave velocity determined in the natural conditions of the coal deposit $(1950 \mathrm{~m} / \mathrm{s})$ on the basis of previous seismic measurements in the coalbed 510 . 


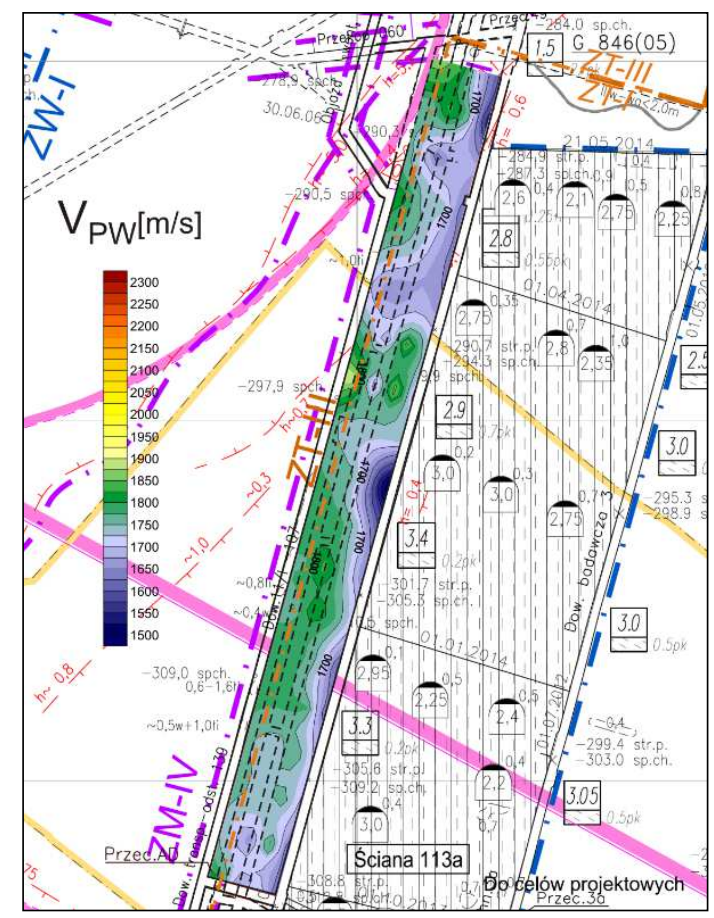

Fig. 3. P-wave velocity field within the coalbed (shortwall panel AD) [12].

Actually, the distribution of the seismic anomaly parameter is associated with redistribution of stresses within the coalbed, hence the positive value of the anomaly parameter in excess of $5 \%$ is indicative of stress increase whilst the negative values correspond to the weaker zones within the coalbed, including the de-stressing zones. Within the shortwall panel the averaged value of the seismic anomaly parameter equals $-11 \%$ (Fig. 4), indicating that the mean vertical stresses are below the levels registered in the lithostatic conditions (associated with depth of deposition). For a single de-stressing operation involved in the mining system with hydraulic backfilling, the computed time required for effective destressing based on an averaged value of the seismic anomaly parameter will exceed one year; in the case of repeated de-stressing operations (involving the backfilling system) this time period equals three years from the date of the survey. Alongside the upwards heading 139 (within the belt $5 \mathrm{~m}$ wide) the average value of the seismic anomaly parameter becomes $-9 \%$, varying from -4 to $-14 \%$, whilst in the proximity of the upwards heading $11 /$ III-115 its varies from -10 to $-25 \%(16 \%$ on the average). Actually, the seismic anomaly parameter distribution suggests that the stress concentration zone in the vicinity of the upwards heading 139 is connected to the fracturing zone due to the coalbed 510 being mined at the edge of its layer II, and to the zone caused by mining operations in the top layers (from the eastern end). Generally, the value of seismic anomaly parameter tends to decrease in the direction from the upwards heading 139 towards the heading 11/III-115. As the values of the anomaly parameter in excess of $-7.5 \%$ are associated with the limited de-stressing efficiency zone, the de-stressing efficiency along the upwards heading 11/III-115 and its direct vicinity is on the average level, due to one or two layers in the coalbed 510 being mined-out. Within the belt of the undisturbed coal body extends up to $5 \mathrm{~m}$ from the upwards heading 139 , the fracturing zone emerging around the mine working and along the edge in the coalbed 510 gives rise to the weak de-stressing effect. Locally, over short segments, the negative value of the anomaly parameter corresponding to the de-stressing action tends to increase beyond $-7.5 \%$; however, 
there have been no reports of its value exceeding zero, which would be indicative of stress increase [12].

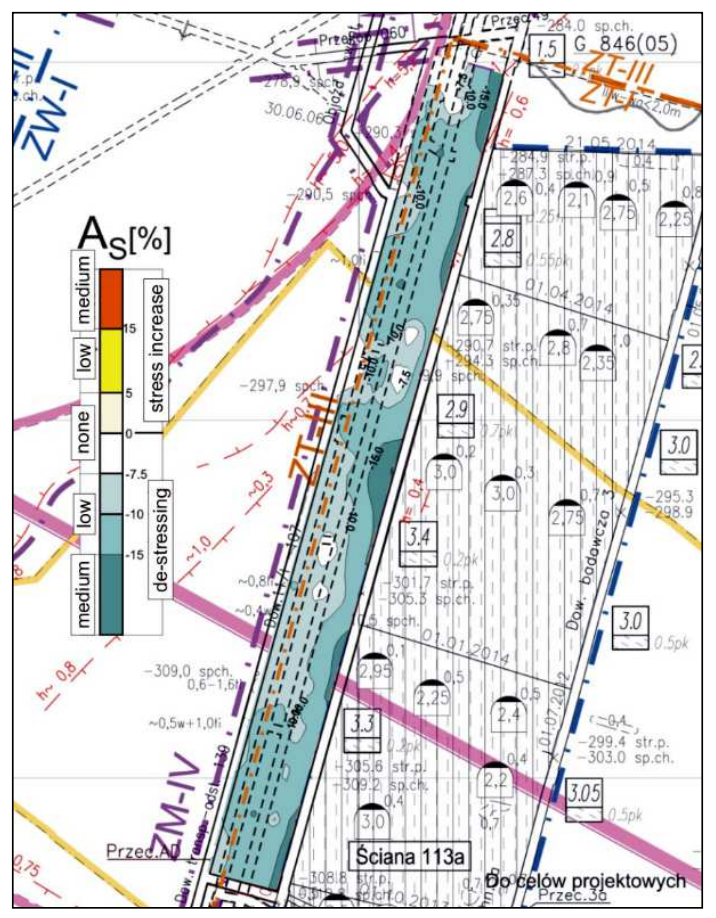

Fig. 4. Distribution of the anomaly parameter in the coalbed (shortwall panel AD) [12].

In the light of these considerations and the fact that the areas of lower $\mathrm{P}$ wave velocity (with respect to the natural conditions) identified in seismic surveys and characterised by the negative value of the seismic anomaly parameter are indicative of the stress de-stressing zones (in relation to the lithostatic conditions), it is reasonable to expect low and stabilised rockburst threat levels in the shortwall plot AD.

\section{Analysis of the state of stress and rockburst hazard in the light of analytical modelling}

From the geomechanical point of view, the decisive factors controlling the rockburst hazard include:

- the primary state of stress, associated with the mining depth, the impacts of the previous mining operations and tectonic disturbances,

- geomechanical properties of the rock media in the regions of mining activities,

- induced seismicity of the rock strata, due to potential activation of shock-prone strata.

At the stage of design of new mining operations or in the absence of reliable seismicity data, the rockburst hazard assessment has to rely in the first place on prediction of stress levels (by analytical or numerical methods) related to the resistance parameters of the rock medium. Actually, the factor controlling the rockburst occurrence is the presence of critical stress concentration zones in the proximity of mine excavations. Consequently, this evaluation of the rockburst threat in the shortwall panel AD relies on analytical simulation data (in the form of contour maps) [13] defining the vertical components of the primary stress tensor (Fig. 5) and the coefficient of stress concentration (Fig. 6). 


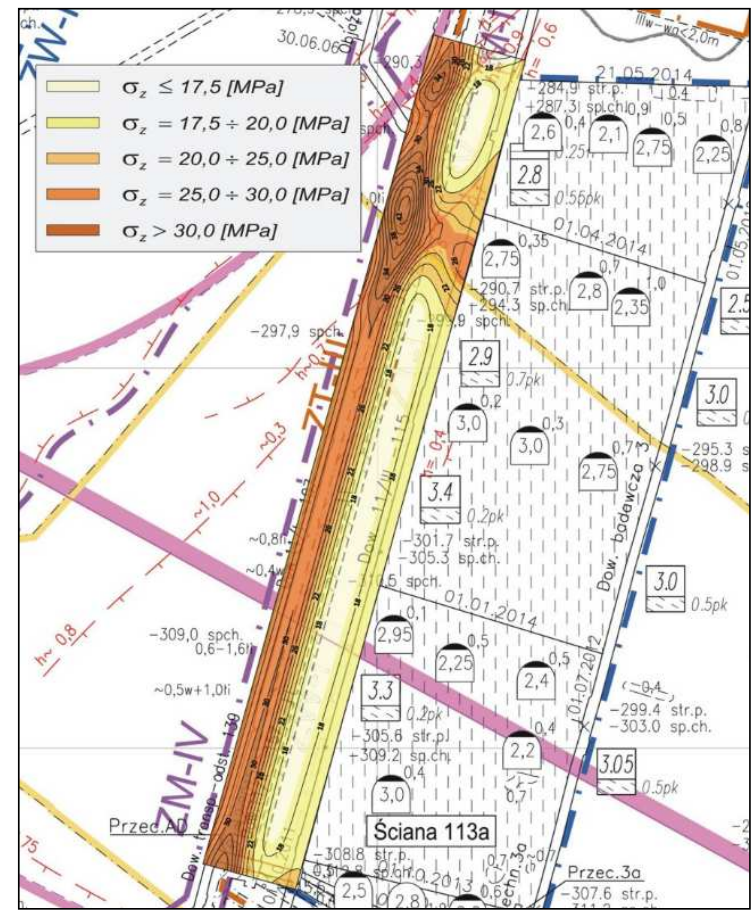

Fig. 5. Vertical stresses in the region of the shortwall panel AD [13].

Calculations show that the state of stress in the investigated shortwall plot (between the upwards headings 139 and 11/III-115, the cross-cut AD and the final segment of the face range 113a) is non-uniform, which can be attributed to the impacts of previous mining operations. Simulation data indicate that the value of the vertical stress component falls in the range $14.9 \div 43.3 \mathrm{MPa}$ (Fig. 5), so locally they exceed the uniaxial compressive strength of the coal, giving rise to the stress concentration zones within the coalbed. On the other hand, variability of the stress concentration factor expressed as the product of the primary and gravity-induced stresses varies from 1.03 to 2.98 (Fig. 6), which suggests that the de-stressing (stress relief) effect does not occur within the shortwall panel whilst the undercutting can lead to destructive de-stressing, of primary importance in the context of rockburst threat control. Stress concentration zones revealed on the contour maps are attributable to superimposed interactions of edges of the face end 111 (layer I within the coalbed 510) and 112 (layer II); of exploited excavations adjacent to the longwall face 113a (layer III) and the impacts of previous mining activities in the coalbed 510 distant by about $20 \mathrm{~m}$, along the final segment of the shortwall section. In its major part, the shortwall plot is affected by previous undercutting of two layers of the coalbed 510 (top roof and middle layer) so the destructive de-stressing effect is manifested through changes of geo-mechanical properties of the top layer within the investigated coalbed. The existing edge 113 in the seam 620 does not significantly contribute to the state of stress in the shortwall panel AD because the vertical distance between the respective seams is sufficiently large $(140 \mathrm{~m})$. 


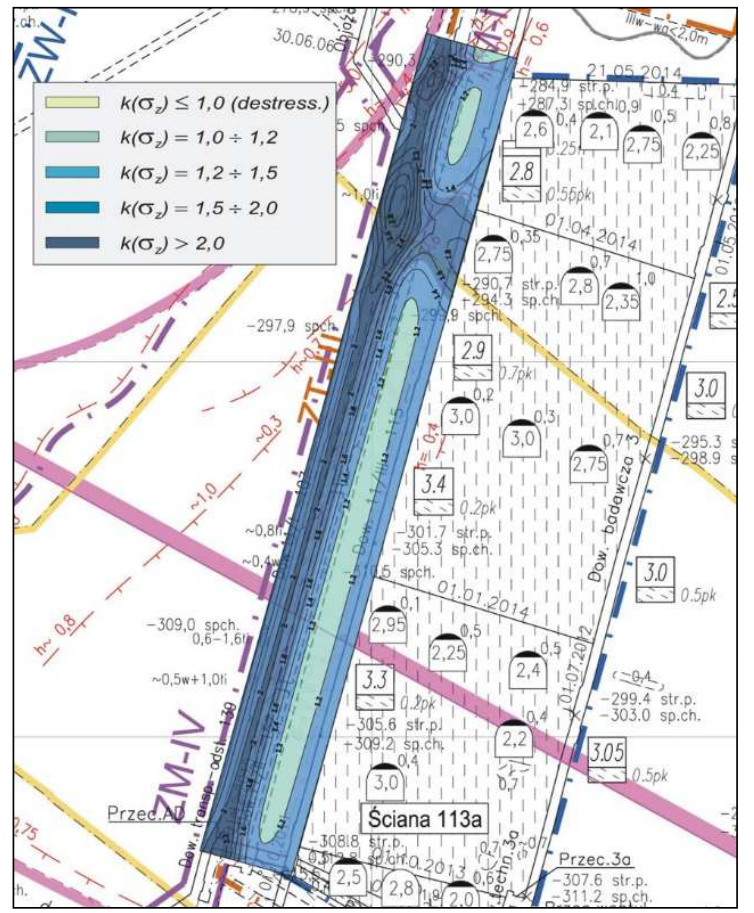

Fig. 6. Map of vertical stress concentration factor in the shortwall panel AD [13].

When evaluating the rockburst threat, two distinct phases of mining operations have to be considered when the involved threat levels will be different. In the first phase, when mining activities are continued in the section underneath the mined-out seam 510 the rockburst threat level will be relatively low because the major portion of seismic energy of potential quakes will be dissipated in old exploited excavations. In the second phase, when the mined section of the face range extends beyond the exploited workings within the seam 510 , the rockburst threat levels will be elevated because the physical effect of seismic energy dissipation will not occur. The most threatened site (in the context of rockburst threat forecast and the presence of coal in the floor strata) will be the upwards heading 139 and the belt of undisturbed body of the coal deposit abutting to it.

\section{Conclusions}

With reference to the geological and mining conditions in the area, the study synthesises the key aspects involved in the development of the state of stress and the de-stressing effects experienced during mining operations in one of the collieries in the Upper Silesia Coal Basin. Seismic tomography data and the results of analytical simulations are interpreted and compared. Of particular interest was the belt-like section of undisturbed coal panel (40x35m) within the shortwall panel AD in the top layer of the seam 510 , at the depth of $600 \mathrm{~m}$. The main objective of the investigations was to compare the geophysical survey data with analytical results obtained by the methods of strata mechanics in the context of rockburst hazard assessment prior to projected mining operations.

The comparative analysis leads us to the following conclusions:

- Even though the results obtained by the methods are not fully correlated, the state of stress in the shortwall panel AD is actually regarded as non-uniform, which can be attributed to previous mining of the coal seams 510 and 501. 
- Analytical results suggest the occurrence of stress concentration zones due to the superimposed impacts of the edges of old exploitation, which is not corroborated by the geophysical survey data.

- Seismic survey data indicate a well-identified though non-uniform de-stressing effect in the shortwall plot due to previous mining of the two layers in the coal seam 510; its effectiveness being categorised as low or medium.

- According to the geophysical survey data, the coal seam 510 within the shortwall plot $\mathrm{AD}$ is generally not rockburst threatened even though its structure still retained to accumulate elastic energy. Analytical data suggest that rockburst threat in the course of mining operations will vary, depending on the actual position of the face front in relation to energy-dissipating gob areas within the coal seam 501.

\section{References}

1. J. Dubiński, W. Konopko, Tapania - ocena, prognoza, zwalczanie (Rock bursts assesment, prognosis, defeating), Wyd. GIG Katowice (2000) (In Polish)

2. J. Dubiński, Z. Pilecki, W. Zuberek, Badania geofizyczne w kopalniach - przeszłość, teraźniejszość, i zamierzenia na przyszłość (Geophysical research in mines - past, present and future plans) Wyd. IGSMiE PAN, Kraków (2001) (in Polish)

3. J. Dubiński, Sejsmiczna metoda wyprzedzajacej oceny zagrożenia wstrzasami górniczymi w kopalniach wegla kamiennego (Seismic method of shock threat assessment in hard coal mines) Central Mining Institute, Katowice (1989) (in Polish)

4. Czarny R., Marcak H., Nakata N., Pilecki Z., and Z. Isakow, Monitoring Velocity Changes Caused By Underground Coal Mining Using Seismic Noise. Pure and Applied Geophysics 173 (6), 1907-1916 (2016) doi: 10.1007/s00024-015-1234-3

5. Z. Pilecki, Zastosowanie rejonowej obserwacji sejsmoakustycznej do kontroli stanu zagrozenia tapaniami (The use of zonal seismoacoustic observations for rockburst hazard monitoring). Publ. - Institute of Geophysics, Polish Academy of Sciences, Series M, M-16 (245) 203-216 (In Polish)

6. Z. Szreder, Z. Pilecki, J. Kłosiński, Comparison of Profiling Results of Attenuation and Velocity of Refracted P-wave in Coal-seam, Proc. 14th EAGE European Meeting of Environmental and Engineering Geophysics (2008) doi: 10.3997/2214-4609.20146265

7. E. Glowacka, Z. Pilecki, Seismo-acoustic anomalies and evaluation of seismic hazard at the 'Marcel' Coal Mine, Acta Geophysica 37, 1, 47-59 (1991)

8. Z. Pilecki, An Example of Rock Burst Hazard State Control Using a Zonal Seismoacoustic Observation. Proc. Fifth Conf. on Acoustic Emission/Microseismic Activity, Trans. Tech. Publications, Clausthal-Zellerfeld, 313-332 (1995)

9. A. Jakubów, Z. Szreder, Z. Pilecki, E. Pilecka, Zabezpieczenie robót górniczych poprzez obserwacje sejsmoakustyczne na przykładzie KWK Jastrzębie (Application of seismoacustic observations for safety measures of mining works: example from Jastrzebie coal mine). Publ. Inst. Geophys. Pol. Acad. Sc. M-19 (281) 209-215 (1995) (In Polish)

10. M. Kwaśniewski, J. Wang, Analiza numeryczna deformacji górotworu wywołanych eksploatacja górnicza (Numerical analysis of mining-induced deformations of the rock mass), Proc. of the School of Underground Mining, 153-187 (1996) (in Polish)

11. Z. Pilecki, Dynamic analysis of mining tremor impact on excavation, Proc. Int. FLAC Symp. on Num. Model. in Geom., Detournay \& Hart, 397-400 (1999) 
12. Report, Ocena stanu zagrożenia tapaniami oraz określenie stopnia odprężenia III warstwy pokładu $510 \mathrm{w}$ rejonie planowanej eksploatacji ubierka na wybiegu $450 \mathrm{~m}$ na podstawie pomiarów geofizycznych (Assessment of rockburst threat and de-stressing effect in the layer III within the coal seam 510 in the region of projected shortwall mining activities on the face range section $450 \mathrm{~m}$, basing on geophysical survey data), AgosGemes Sp. z o.o., Katowice (2016) (in Polish, unpublished materials)

13. Report, Ocena i analiza naprężeń $w$ górotworze skłonnym do tapań $w$ aspekcie eksploatacji w latach 2015-2017 w zakresie projektowanej eksploatacji ubierka AD w partii wschodniej poktadu 510 (Assessment of state of stress in burst-prone rock strata due to mining activities over the years 2015-2017 in the context of projected shortwall mining operations in the eastern section of the coal seam 510, with the main focus on rockburst threat assessment procedures), Research and Technical Bureau Geotech II, Krakow (2016) (in Polish, unpublished materials)

14. A. Sałustowicz, Zarys mechaniki górotworu (Fundamentals of strata mechanics), Slask Publishers (1968) (in Polish)

15. M. Borecki, M. Chudek, Mechanika górotworu (Strata mechanics), Slask Publishers (1972) (in Polish)

16. Zorychta, Kryterium powstawania tapań przy eksploatacji pokładu węgla kamiennego (Criteria of rockburst occurrence during coal mining), AGH Journal of Mining and Geoengineering 125, (1984) (in Polish) 